

\section{Technical and Bibliographic Notes}

The Institute has attempled to obtain the best original copy available for filming. Features of this copy which may be bibliographically unique, which may alter any of the images in the reproduction, or which may significantly change the usual method of filming are checked below.

\section{Coloured covers /}

Couverture de coule'dr

Covers damaged /

Couverture endommagée

\section{Covers restored and/or laminated/}

Couverture restaurée et/ou pelliculée

Cover title missing / Le titre de couverture manque

Coloured maps / Cartes géographiques en couleur

Coloured ink (i.e. other than blue or black) /

Encre de couliur (i.e. autre que bleue ou noire)

Coloured plates and/or illustrations /

Planches etou illustrations en couleur

Bound with other material /

Relié avec d'autres documents

Only edition available /

Seule édition disponible

Tight binding may cause shadows or distortion along interior margin / La reliure serrée peut causer de l'ombre ou de la distorsion le long de la marge intérieure.

Blank leaves added during restorations may appear within the text. Whenever possible, these have been omitted from filming / II se peut que certaines pages blanches ajoutées lors d'une restauration apparaissent dans le texte, mais, lorsque cela était possible, ces pages n'ont pas èté filmées.

Additional comments /

Commentaires supplémentaires:
L'Institut a microfilmé le meilleur exemplaire qu'il lui a été possible de se procurer. Les détails de cet exemplaire qui sont peut-être uniques du point de vue bibliographique, qui peuvent modifier une image reproduite, ou qui peuvent exiger une modification dans la méthode normale de filmage sont indiqués ci-dessous.

\section{Coloured pages / Pages de couleur}

\section{Pages damaged / Pages endommagées}

Pages restored and/or laminated /

Pages restaurées et/orı pelliculées

Pages discoloured, stained or foxed /

Pages décolorées, tachetées ou piquées

Pages detached / Pages détachées

Showthrough / Transparence

Quality of print varies /

Qualité inégale de l'impression

Includes supplementary material /

Comprend du matériel supplémentaire

Pages wholly or partially obscured by errata slips, tissues, etc., have been refilmed to ensure the best possible image / Les pages lotalement ou partiellement obscurcies par un feuillet d'errata, une pelure, etc., ont été filmées à nouveau de façon à obtenir la meilleure image possible.

Opposing pages with varying colouration or discolourations are filmed twice to ensure the best possible image / Les pages s'opposant ayant des colorations variables ou des décolorations sont filmées deux fois afin d'obtenir la meilleure image possible.

This item is filmed at the reduction, "atio checked below /

Ce document est filmè au taux de réduction iridiqué ci-dessous.

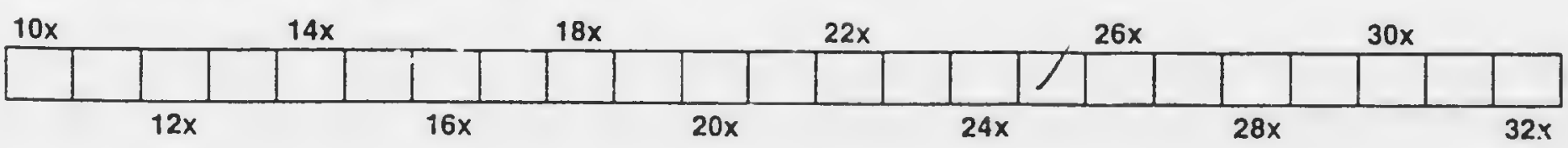


The copy filmed here has been reproduced thenks to the generosity of:

University of British Columbia Library Vancouver

The images appeering here are the best quality possible considering the condition end legibility of the original copy and in keeping with the filming contract specifications.

Originel copies in printed peper covere are fllmed beginning with the front cover and ending on the lest page with a printed or illustreted impres. sion, or the beck cover when appropriate. All other originel copies sp's filmed beginning on the first pege with a printed cr illustrated impres. sion, and ending on the last pege with a printed or illustrated impression.

The last recorded freme on eech microfiche shall contain the symbol $\longrightarrow$ Imeaning "CON. TINUED"). or the symbol $\nabla$ (meaning "END"). whichever applies.

Maps, pletes, charts, otc., mey be filmed at different reduction retios. Those too lerge to be entirely included in one exposure are filmed beginning in the upper left hend corner, left to right and top to bottom, as meny frames as required. The following diagrams illustrate the mothod:
L'exemplaire filmó fut reproduit gráce à la gond osite de:

University of British Columbia Library Vancouver

Les images suivantes ont oté reproduites avec lo plus grand soin. compte tenu de la condition et de la netrete de l'exemplaire filmo. et en conformitb avec les conditions du contrat de filmege.

Les exemplaires originaux dont la couverture en papier est imprimbe sont filmés en commencant par lo premier plat ot en terminant soit par la dernidre pege qui componte une empreinte d'impression ou d'illustration, soit par le second plet. selon le ces. Tous les autres exemplaires originaux sont filmds en commençant par la premidre pege qui compone une empreinte d'impression ou d'illustration et en terminant par la dernidre page qui comporte une telle empreinte.

Un des symboles suivants apparaitra sur la dernidre image de chaque microfiche, selon le cas: le symbole $\longrightarrow$ signifie "A SUIVRE". le symbole $\nabla$ signifie "FIN".

Les cartes, planches, tableaux, etc.. peuvent ètre filmos a des taux de reduction différents. Lorsque le document est trop grand pour ètre reproduit on un soul cliché. il est filmé à partir de l'angle supdrieur gauche. de gauche d droite. et de haut on bas, on prenant le nombre d'imeges nécessaire. Les diagrammes suivants illustrent la mothode.
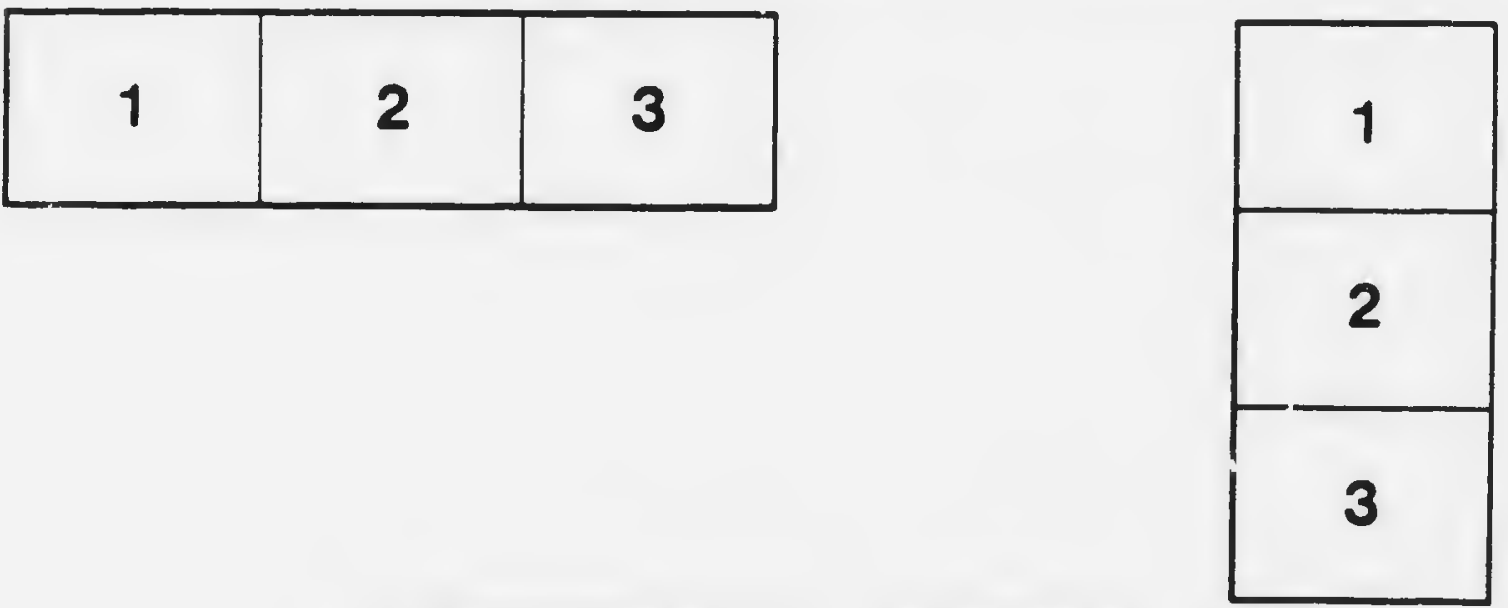

\begin{tabular}{|l|l|l|}
\hline 1 & 2 & 3 \\
\hline 4 & 5 & 6 \\
\hline
\end{tabular}




\section{MICROCOPY RESOLUTION TEST CHART}

ANSI and ISO TEST CHART NO 2
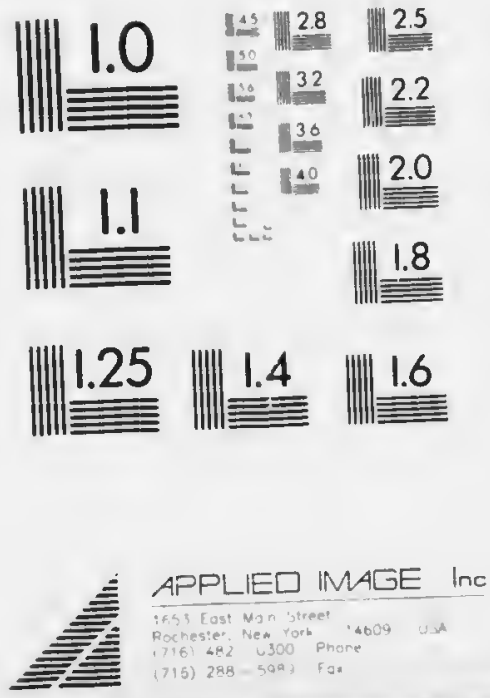

SD415 - G 8

\section{Diseases of Forest Trees}

A. ADDRESS DEI,IERED BY MR. H. T. GÜSSOW BEFORE THE FIRST ANNLAL IEETING OF TIIE COMMISSION OF CONSERVATION 

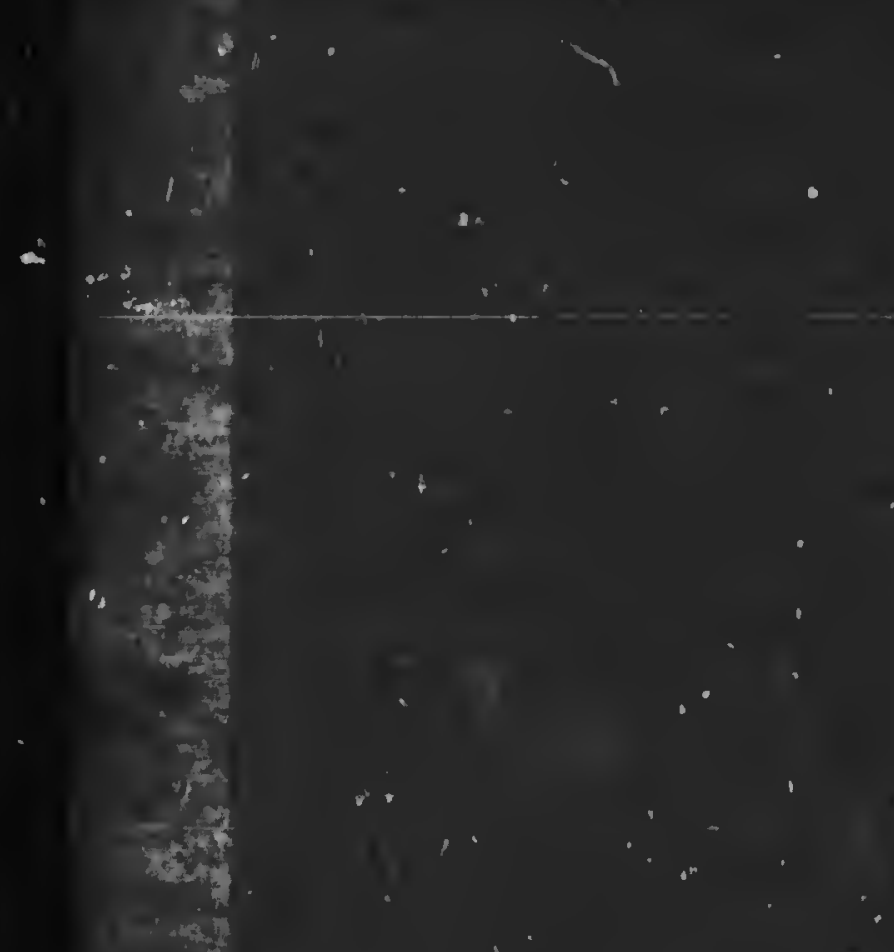


\title{
Diseases of Forest Trees
}

\author{
AN ADDRESS DELIVERED BY MR. H. T. GÜSSOW \\ BEFORE, THE FIRST ANNUAL MEETING \\ OF THE COMMISSION OF CONSERVATION
}




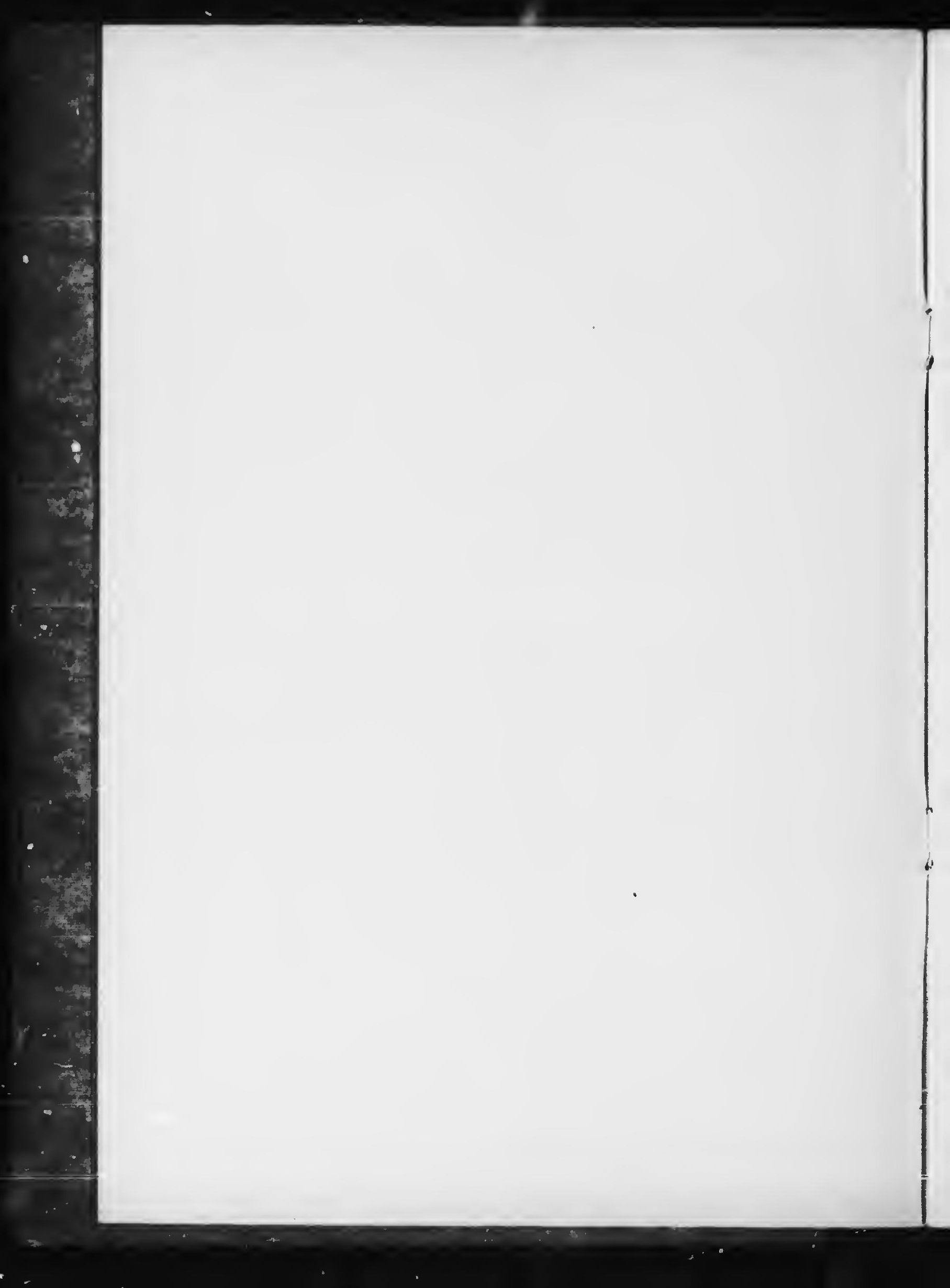




\section{DISEASES OF FOREST TREES}

Considcrable attention has been paid in the past to the study of forest tree diseases, especially in countrics where it was realizerl that closing one's eves much longer to the existing dangers woult result in serious losses to tratle and commerce. This extremely uscful study has revealed to a consilerable degree the economic importance of the disease-causing organisuns which may attack our forest resources.

Unfortunately, as yet, very little attention has heen paid to this subject in Canada. Canala's supply of timber has of ten been said to he inexhaustible, and practically anylooly provided with the necessary capital and permission could go and fell trees to his heart's content. There was no question of selecting, of careful consideration or of economy; the future would take care of itself; there was enough fcrest land to supply the whole world with timberl Yet what is the good of closing one's eyes to the fact that it may take a day to pull lown a tree, but many years to grow one?

I forget, however, that I an addressing the menters of the Commission of Conservation, all of whom are far more familiar than I, with this methori of silent devastation that las been practised for soine time. It is $m y$ intention to speak on diseases of forest trees, and I have seleeted from among a large number a tew that to me appear to be of the greatest econonic importance.

As far as the maladies of other plants are concerned, the public have had their eyes opened and little urging is required to get them to employ the best means for checking the growth of parasitic fungi, which affect the pocket by injuring the crops, or diminish our enjoyinent $b y$ disfiguring our fields and gardens. But, with regard to forest trees, there is a regrettable indifference, just as if diseases could not possibly harm them, and yet, severe losses do result annually from such fungus epidemics, which are in no way checked in their progress.

Speaking generally, the diseases of trees may be divided into two groups: First, those caused by mechanical or physical conditions; and second, tlose where parasitic organisms, such as insects and fungi, are the principal agents involved. With some of the more important insects, my colleague, Dr. Hewitt, Dominion Entonologist, no doubt will 
deal, and lence the present remarks will lie confined, for the most part, to diseakes of forest trees caused by parusitic fungi.

It is a common olservation that different types of soil unl climate support different kinds of trees and other plants. 'The study of this suliject has more recently engagel the attention of the licologist. But it is not always that we find certain trees growing in certnin soils and under certain conditions, for the simple reason that man's efforts introduce trees into environments not peculiar to them. Nurseries and plantations of any kind supply exceltent examples of their growing under conditions enforcel upon them. l'arts of our forests which have been clcared may again be desired to serve for the raising of young forest trees, and it is here where frequent failures are experienced. For we must bear in mind that the natural conditions are now totally changed; where formerly a humid atınosphere was present, we have now more air, and where natural shade prevailed, we have more light. The young plants that nay be raised in such open woods are exposed to a marked degree to such physicul influences, whicls sould, under the old conditions, exert no irijurious influence.

This exposure to physical conditions, however, is not the only factor which may induce disease; the trees are especially exposed to infections from other sources. There is particularly one fungus enemy of young seedling conifers which is known as the "Damping-off fungus." When the young seedlings have grown to a certain size under this new condition, it is by no means a rare occurrence that they suddenly begin to the in larger or smaller patches, and, if no means are employed to check this progress of dying off, soon all the seedlings will succumb, and any that are planted thereafter will fall victims to some mysterious foe. The cause for this sudden failure is now thoroughly understood; it has been found to be due to a microscopic fungus which attacks the young plants at the base and kills them with grear rapidity. This disease in young coniferous trees is very serious, and it is fortunate that means have been discovered to prevent it. For although we shall not for some generations experience any shortage of forest supplies, providing, of course, that some method is discovered for fighting that arch enemy, "Forest Fire," we must bear in mind that planting young trees is the next inportant problem in the conservation of our forests. In some countries the annual planting of certain areas with young forest trees is enforced by legislation, and, on the whole, the lumberman is much checked in injudiciously cutting down timber trees. The best results in preventing the damping-off of coniferous seedlings were obtained by treating the soil several days before sowing the seed, by thoroughly drenching it with a solution mixed in the proportion of 
one ounce of sulphurie acid to one gallon of water. Thi treatment was repeated about a week after the seellings came up. Checkplots were usel in these experiments which reeeivel no treatment aucl they had practieally no seetlings left, while, in the treated plots, there was a good stand of fine healthy seedlings.

It is possibly due to the presence of this "damping off" fungus and its gevere losses that, cluring recent years, la rge shinmenis of young forest trees lawe lieen inported into Canada from foreign countries, especially Europe. 'This inportation is partly practivel to obtain young seerlings of two or more years of age which are past the stage of infertion from this fungus, and partly, hecause they can be obtained at such clieap) rates that eousiclerable time und unoney are saved. Ancl eertainly, noboly could raise any objection to these importations, although, quite recently, together with these seelling eonifers, there is reason to believe, that a very serious disease was imported which may develop into a dangerous enemy to our white pine forests. This throws a very different light on the practice of intporting seedlings. Unfortunately we have enough diseases of our own and (lo not want the introduction of new ones, which, like the new "blister-rust" of pines, as this clisense is termed, would endanger not ouly the lienlth of our seelling trees, but attack our own original resources in the shape of old trees, as well.

In the spring of $1909,200,000$ white pine seellings were imported from Europe into Canala. These seelling plants were stated to be attreked by the fungus causing white pine rust, a disease which has cuusel great devastation anongst pines in many European countries. Unfortunately the pine seedlings were not carefully examined when imported, and were planted out. However, they are quarantined and are now elosely watched. I will show you, later, a few lantern slides, one of which illustrates this disease and gives details of the life history of this parasitie fungus. During one stage of its growth the fungus is ensily observed by the presence of numerous orange red powdery cushions growing from a blister or swelling on the stem of the young pine, but which will appenr also on the branehes and twigs of older trees. The fungus produces a large number of spores. of au orange red eolour, inasses of which form the clusters already described. Spores of fungi may be eompared to seeds of higher plants, because they are capable of germinating similarly to seeds and thus, of course, disseminate and spread the disease. They are very minute, so that a single spore eunnot be seen unless exanined with a microscope. In consequence of their minuteness the spores are borne easily by the air and on windy days may be carried miles away from the infected areas. The disease, however, perpetuates itself, not only 
by means of the spores, but atso by the rootlike extremely delieate, nic roseopic tubes which grow in the tissues of affecter plants and which will protuce, in the subsequent season, a new crop of spores.

There is another factor peculiar to nearly all rust fungi which increases still more the serious nature of the disease. The spores of rust fungi generally pass through another stage in their life history upon uther plants. Thus the white pine rust spors, when shed, are not capalle of germination on other pines directly, but they attack all kinds of cultivated and wild plants helonging to ti.e gooseberry or eurrant tribe. The leaves of these plants are necessary for a further development in the life cycle of this particular fungus. My illustrations will show you the effect of the spores on leaves of currants. Here the spores rapiclly germinate, causing many small redlish pustules to appear on the surface of the leaves, and in these pustules anointer form of spore is produced, which, in conclusion of the cycle of the fungus, is capale of germinating only on pine seedlings. This process repeats itself with every new generation of spores on the pines. Thus we have : First, spores developing on the pine, then passing through the second stage on leaves of gooseberries or currants, where they produce anotlier crop of spores, which return to the pines in continuance of their cycle of life.

I clo not interd to deseribe the clamage due to these spores on the berry bushes, hut shall just say that the damage there may also be considerable. I have no doubt that you will agrce that we have here to deal with a very serious enemy of our forest trees, and that my reference to this parasite will make forest nurserymen careful. Linder no conditions should pines attackerl by rust be planted, and precautions should be taken when inporting young seedlings to ohtain them from uninfeeted areas, or to have them examined on arrival in Canada by a competent hotanist who is able to recognize the disease in all its symptoms. Since it is evident that pines and likes plants are both necessary to the development of the white pine fungus, the destruction of either hind of hosts must result in the extermination of the rust. Wherever the pines are attacked a search should be made all ovel the neighbourhood for Ribes and their destruction proceeded witii.

A disease whieh seriously affects the value of timber occurs on our larches or tamaraeks. I propose to give you a short account of the disease, which is known elsewhere as "larch canker." The same disease is reported to appear in the larch groves of North America and Canada, although practically no measures are employed on this sile of the Atlantic to check it. The symptons of this disease are the peculiar flattening of the trunk of liarch trees, the copious outflow of resin and 
the niore or less complicated cankerous spots on the stems or branches of trees. If these affected parts are regularly examined, there may be discovered at certain tinies a small whitish cup-shaped fungus, growing on the surface of the diseased bark. I shall, later on, slow you a slide or two illustrating the disease and its cause. The fungus caps grow from the roots or mycelium which lives in the bark of the trees, and thus they nay be produced, accorling to the severity of the disease, in more than one place. The sinall cups inay often be observed on all parts of the trees, even to the sinallest branches.

When larch canker is present and this fungus spore germinates on the bark, it pushes out its germinal tube into the tissues of the bark, where it rapidly branches and permeates the bark and extends into the active layer below from which the new wood and bark is fornerl. In consequence of this irritation the bark is killed and the functions of the active layer underneath it are arrested. The fungus grows year after year and the portion killed increases in size. The tree now inakes every endeavour to lieal these wounds by sending forth from the edges of the wound numerous new cells which try to cover the diseased part. Curiously, this fungus has its active and its passive states; during the latter the tree exerts its powers in producing new tissues intended to cover the wound, which new tissues are vigorously attached by the parasite during its activity. A natural consequence is the survival of the strongest. This batile may go on for years, but in very few cases, will the tree le the victor. II slides will show you some of the complicated results after a number of years of this battle for existence. The result of such infections of a whole plantation is of serious economic importance; the timber is practically useless as such, and trees frequently break off at the infected places through the weight of snow or by the force of the winl.

To prevent these serious coniplications the trees should he carefully examined when young, and, when the first symptoms of the disease are observed, the best method to arrest the progress of the parasite would be to cut away with a sharp knife all diseased bark down to the healthy tissues and paint the surface immediately with a coat of white learl paint.

These few exaniples may suffice to illustrate the seriousness of forest tree diseases caused by microscopic fungi. I will now refer to some diseases caused by the larger fungi which live on timber trees generally. These fungi may grow entirely on living tissues or they may occur on timber after it has been cut down. In botli instances their economic importance is considerable. I lave brought a specimen, which shows on the stem of a white birch a specimen of the wood 
destroying fungi with which I intend to deal. The fruiting bodies of these fungi are familiar sights on dead and living trees, on railway ties, on the timber in mines, in houses, ete. I am sure every one of you will recollect having seen them actually growing. In either case, whether growing on dead or living wood, we find the wood cells filled with minute, fine hreads which penetrate in all directions. The mycelial threads of the fungi concerned in these attacks secrete a ferment acting upon the contents of the living cell. In a short time the death of the cell results and ultimately of the tree. The nycelium may also be present in trees that have been cut down, or in logs, boards, etc., where it will continue to grow till the woud is wholly decayed, that is. when all substances are dissolved which the fungus uses for food. The decay is very rapid in the so-called sap wood of the tree, which contains considerable quantities of starches and oils, while it makes much slower progress in the heartwood. Not until the threads of the fungus grow out from the wool into the air will it be noticed that a tree is diseased. Up to that time there is no external evidence of divease. The threarls which appear outside the bark of a trees give rise, in some cases. to a mere film, such as is shown growing on this specinen, or they may form complicated structures, usually called "toadstools," or those hard, brownish knobs called bracket fungus, a specimen of which 1 have shown growing on the birch. For a long time these ohjects were regarded as growing on the rotted wool, and it was not intil recent times that we learned that the decay' was due to them. From these remarks, you will understand that when you oberve any "bracket" or other fungus growing out of the trunk of a tree, it is really badly decaved withiu. The structure of these fruiting bohlies is very valied; my slides will show you the most common ones and also the danage due to them.

'That you may uis 'erstand how the disease of timber trees is spread. I heg your attention for a few monents to review the structure of some of these disease-causing organisms. The specimen on the birch which I have pased round shons on the lower surface a large nuniber of small oval pures. Hence the seientific name of Polyporus is given to this particular fungus. When a section is made through this layer of pores one can observe, by the aid of a microscope, a number of very minute oral bodies which are the spores of this fungus. When these spores are liberated they may he carried to other trees, and if they find suitable conditions for their development, they will start the decay which makes progress internally. When it is later cliscovered that fruiting bodies of fungi appear on the stem or trunk, it is too late to save the tree. The spores prefer for their development a wound that may be 
present on the bark of trees. In a forest, such wounds are very numerous, branches continually break off, woodpeckers make holes in stems in their hunt for trunk borers, boring beetles themselves puncture the bark, and there may be many other causes. Experience shows that open wounds are dangerous in plants, as they are in animals. Every surgeon recognizes the clangers attending upon wounds in animals, and, before the days of antiseptic treatment, the dangerous, and often fatal, results of operations were due, in many cases, to the infection of wounds by germs fro:n the air. So with unattended wounds of trees. They may easily become infected with fungus spores or other disease germs, ancl with fatal results.

From these olsservations, it is evident in which clirection salvation lies. And, if the Commission of Conservation woulcl institute some method of inspection of forest reserves and plantations, it wouid be one of the most important steps in the direction of conservation of one of the most important natural resources of Canala.

In concluding my address I wish to make a few remarks on the relation of insects to forest iree diseases. My colleague, Dr. Hewitt, who will address you on problems of injurious insects of forest trees, will deal with then from the entomologist's point of view. I only wish to say that frequently one nay olserve fungi like Polyporus volvatus growing on branches and trunks of trees in a peculiar sort of arrangement. On careful examination, it has generally been discovered that the fruiting bodies of this fungus issue from the punctures in the lark caused by some bark or trunk-boring aetle. For this reason it is very evident that unless war is declarel against the noxious insects, the plant pathologist cannot possibly suggest cures or prevention of diseases caused by fungi which gain an entrance through wouncls caused by insects. I conclude my address by showing you some lantern illustrations which will bring home to you the urgent necessity of protecting our forests from the smaller and larger organisms that annually cause great losses, which, if expressed in figures, would amount to a surprisingly large sum.

After Mr. Güssow's paper, Dr. James Mills asked: Are these methods of fighting disease applicable to forests?

Mr. Güssow: Experience in other countries has taught that such is the case, but it is necessary to have a system of inspection such as they have in Germany. The forests are clivided into certain districts and each district is inspected annually by officials who 
have their men knock off every part which is infecterl, cut off the infecterl limbs or hreak off the fungus tops, so as to present fructification and consequent infection of the neighbouring trees.

1)r. Mills: Does it occur on the younger growth only"?

Mr. (iiissow: Yo, it occurs on all trees, young and old. It is not always the case that these fungi will appear on the branchss ligh up. They are fouml from five to ten feet from the ground and are liroken. off with long poles 10 which weights are attached.

Dr. Mills: You think, then, it is possible to apply these methods to forests?

Ir. Güssow: Yes, but it would he necessary to have some method of forest inspection.

Dr Nlills: Would the breaking off of the fungi destroy them?

Mr. Güssow: No, you must dlestroy them by fire.

1)r. Mlils: Should not a tree so infected be marked?

Mr. Güssow: Yes, that is understood. They should be cut down as soon as possible, otherwise new fungus hodies will be produced. 


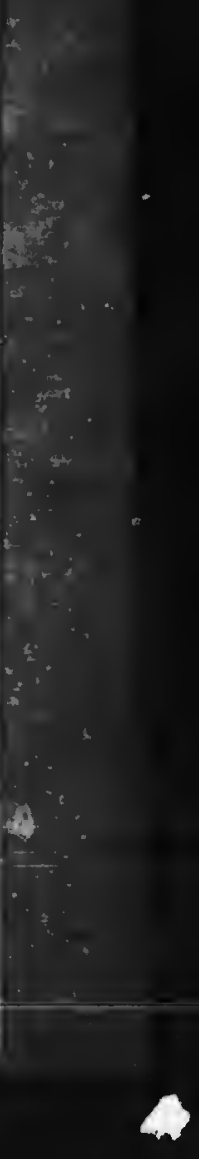




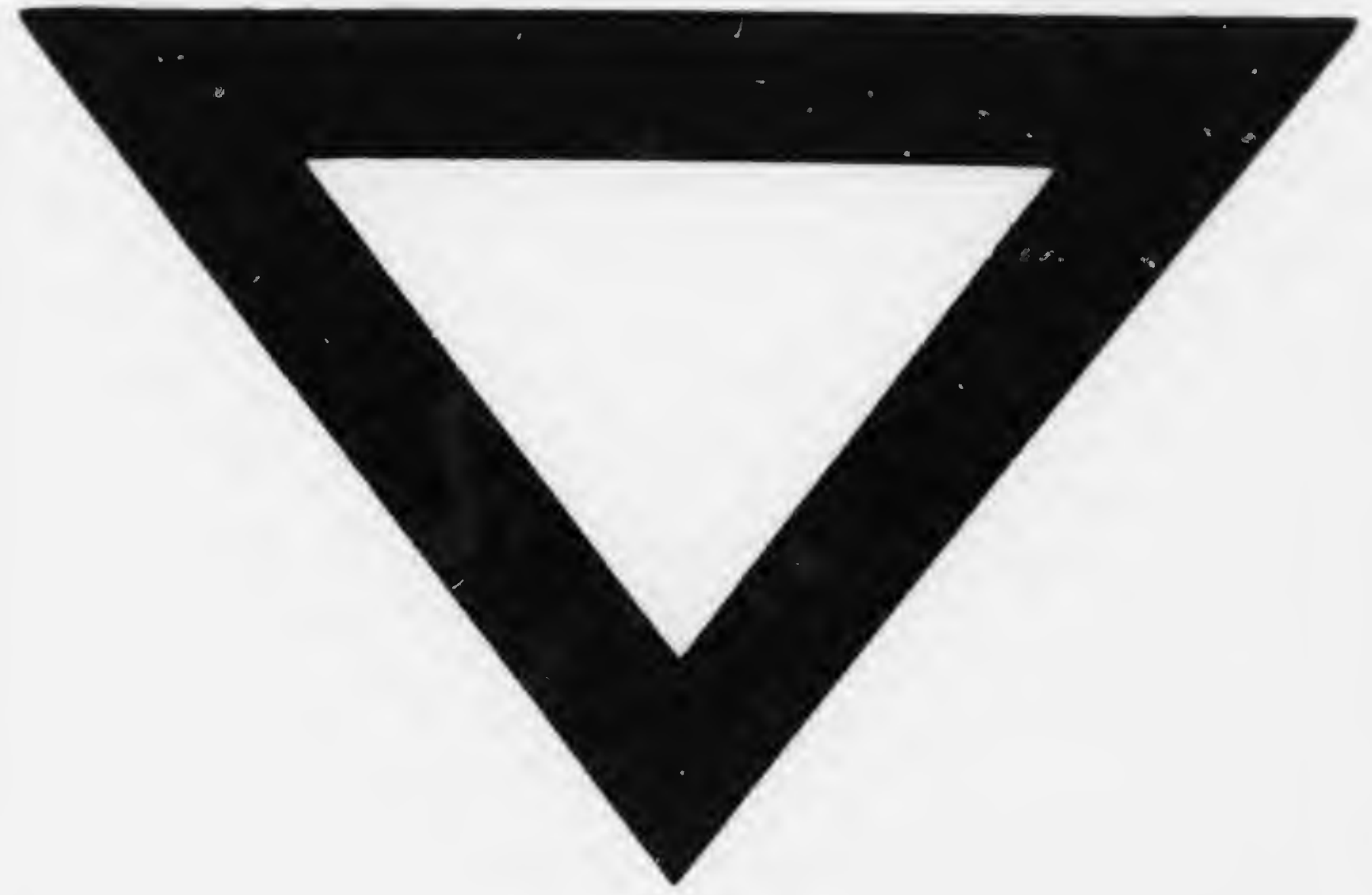

